University of Nebraska - Lincoln

DigitalCommons@University of Nebraska - Lincoln

USDA National Wildlife Research Center - Staff Publications
U.S. Department of Agriculture: Animal and Plant Health Inspection Service

March 2003

\title{
COMMON RAVEN NESTS IN EASTERN KENTUCKY
}

John J. Cox

University of Kentucky, Lexington, $K Y$

Nathan W. Seward

University of Kentucky, Lexington, $K Y$

Jeffrey L. Larkin

University of Kentucky, Lexington, $K Y$

David S. Maehr

University of Kentucky, Lexington, $K Y$

Follow this and additional works at: https://digitalcommons.unl.edu/icwdm_usdanwrc

Part of the Environmental Sciences Commons

Cox, John J.; Seward, Nathan W.; Larkin, Jeffrey L.; and Maehr, David S., "COMMON RAVEN NESTS IN EASTERN KENTUCKY" (2003). USDA National Wildlife Research Center - Staff Publications. 515. https://digitalcommons.unl.edu/icwdm_usdanwrc/515

This Article is brought to you for free and open access by the U.S. Department of Agriculture: Animal and Plant Health Inspection Service at DigitalCommons@University of Nebraska - Lincoln. It has been accepted for inclusion in USDA National Wildlife Research Center - Staff Publications by an authorized administrator of DigitalCommons@University of Nebraska - Lincoln. 


\title{
COMMON RAVEN NESTS IN EASTERN KENTUCKY
}

\author{
John J. Cox ${ }^{1}$, Nathan W. Seward ${ }^{2}$, JefFery L. Larkin ${ }^{3}$, \\ AND DAVID S. MAEHR ${ }^{4}$
}

\begin{abstract}
Although ravens were once widespread throughout Appalachia they are now considered threatened or endangered in many states of the region. We document a nesting pair of common ravens in an area of southeastern Kentucky nearly $50 \mathrm{~km}$ northwest of traditional nesting sites. Further, we suggest several factors that may have influenced the patterns of raven abundance in the state and offer management recommendations to assist their recovery.
\end{abstract}

Ravens (Corvus spp.) were once widespread in North America, Europe, Asia, northern Africa, and Australia (Wilmore 1977). In some areas, human persecution and habitat loss during the 19th and 20th centuries reduced the raven's abundance and distribution and resulted in its habitation of more rugged and remote portions of its range (Wilmore 1977). However, during the past two decades, ravens have recolonized portions of their former range (Kilham 1989, Saemann 1989) and increased in abundance (Boarman and Berry 1995, Buckelew and Hall 1994) in parts of North America and Europe.

The common raven (Corvus corax L.) was found throughout Kentucky during early European settlement, having been most abundant in the mixed-mesophytic forests of the southeastern Cumberland Mountains and Cliff Section of the Cumberland Plateau (Mengel 1965, Palmer-Ball 1996). Although Mengel (1965) considered the raven extirpated by the late $1950 \mathrm{~s}$, common ravens have been occasionally observed in several locations in southeastern Kentucky since 1970 (Croft 1970, Davis et al. 1980, Heilbrun 1983, Smith and Davis 1979, Stamm 1981), however nesting has rarely been documented. Fowler et al. (1985) first reported ravens nesting in Kentucky at Bad Branch State Nature Preserve (SNP). Larkin et al. (1999) observed a pair of ravens nesting in a cliff (high-wall) on Cyprus-Amax Wildlife Management Area (WMA), a 7,400 ha active surface coal (strip) mine $48 \mathrm{~km}$ north-

\footnotetext{
${ }^{1}$ University of Kentucky, Departments of Animal Sciences and Forestry, Lexington, KY 40546; coyote1701@yahoo.com. ${ }^{2}$ University of Kentucky, Department of Forestry, Lexington, KY 40546; nathanseward@ hotmail.com. ${ }^{3}$ University of Kentucky, Departments of Animal Sciences and Forestry, Lexington, KY 40546; jllark0@ pop.uky.edu. ${ }^{4}$ University of Kentucky, Department of Forestry, Lexington, KY 40546; dmaehr@pop.uky.edu.
} 
west of Bad Branch SNP. Although strip-mining at Cyprus-Amax created the temporary cliff habitat utilized by the ravens, the area was subsequently reclaimed and the nesting site destroyed in early 2000. After destruction of the nest, the authors occasionally observed one or a pair of ravens in flight and/or heard their calls on Cyprus-Amax WMA or at the adjacent Laurel Fork Unit of Robinson Forest WMA. Robinson Forest WMA consists of 4000 ha of contiguous mixed-mesophytic forest and a non-contiguous (Laurel Fork Unit) 1400 ha portion recently strip-mined for coal.

In March 2001, we discovered a raven's nest $4 \mathrm{~km}$ northwest of that reported by Larkin et al. (1999) on the Laurel Fork Unit of Robinson Forest WMA. The nest was located in a crevice approximately $3 \mathrm{~m}$ from the top of a $30 \mathrm{~m}$ strip-mine high-wall that paralleled a graveled haul road (Fig. 1). The nest was approximately $1 \mathrm{~m}$ in diameter and composed primarily of dead, woody limbs in keeping with other descriptions (Harrison 1975, Boarman and Heinrich 1999). During the early spring of 2001, we observed a raven returning to this nest on several occasions and frequently saw one or two ravens flying and/or calling in the immediate area of the nest.

In February 2002, we observed that the raven nest on Laurel Fork was absent from its 2001 location. However, in a nearby rock crevice approximately $5 \mathrm{~m}$ to the left of and below the old nest site we discovered an active raven's nest (Fig. 1). The material in this nest appeared similar in composition to that from the previous year, leading us to suspect that the old nest may have been relocated to this nearby crevice. Between February and mid-April 2002 we routinely observed a pair of ravens bringing food to two nestlings (Fig. 1).

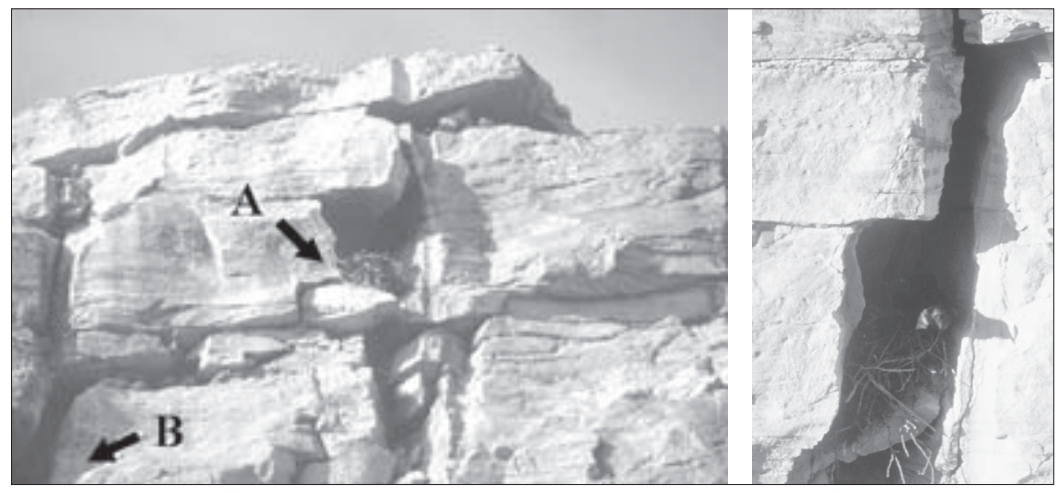

Figure 1. Common raven nest in 2001 (A) and 2002 (B) located in a high-wall on Robinson Forest Wildlife Management Area, Breathitt County, Kentucky (left photo). Raven perched on 2002 nest (right photo). 
Though the statewide extirpation of ravens was largely undocumented, the loss of forest habitat (Harlow 1922), persecution by humans (Nicholson 1997), and extirpation of large herbivores and carnivores (Palmer-Ball 1996) have been implicated as contributing factors to its decline in the eastern United States. Ravens, like many other corvids, are known to scavenge large mammal carcasses (Harlow et al. 1975, Marzluff et al. 1996, Thwaites 1904) provided by a variety of large scavengers and carnivores (Dudek 2001, Mech 1970, Ryden 1975). We observed a raven scavenging an elk (Cervus elaphus nelsoni Erxleben) carcass approximately $600 \mathrm{~m}$ from the raven's nest in April 2001. Buckelew and Hall (1994) partially attributed the recent population increase of ravens in West Virginia to the dramatic increase in white-tailed deer road-kill. Kilham (1989) has suggested that the opening of carcasses by coyotes may be especially important for the recolonization of ravens in New England. The importance of scavengers and carnivores to raven persistence is underscored by the fact that in Kentucky, ravens declined concomitantly with large carnivore extirpation (Young and Goldman 1944, Young and Goldman 1946). The reintroduction of elk to eastern Kentucky (Maehr et al. 1999) and the colonization of this region by coyotes (Cox et al. 2001) represent the return of an important food source and the means by which to exploit it, respectively. Whether or not the raven can successfully utilize these novel resources to facilitate recolonization is yet undetermined.

Habitat change may also be an important factor that has contributed to the recovery of ravens in central Appalachia. Ravens typically prefer mature, contiguous tracts of forest (Bednorz 1991, Boarman and Heinrich 1999, Grünkorn 2001), the largest populations in this region having persisted in the rugged Smoky Mountains of Tennessee (Nicholson 1997) and Allegheny Mountains of West Virginia (Buckelew and Hall 1994). The economy in central Appalachia has largely shifted from agrarian to extractive and service-based during the past 150 years and resulted in the abandonment of farmland and subsequent reforestation (Eller 1982, Kentucky Environmental Quality Commission 2001). Although the forests in this region were heavily logged during the early twentieth century, many have matured during the past century and may have been a contributing factor to raven recovery in these areas.

Although ravens are sensitive to human disturbance (Kilham 1989), recent findings suggest that in some areas, such as the southwestern U.S, they have become well adapted to human environments (Boarman and Berry 1995, Knight et al. 1993, White and Tanner-White 1988). Despite the historical reclusiveness of the raven in Appalachia 
(Mengel 1949, Hooper 1975), our observations of ravens in a highly disturbed area suggest the potential for a similar pattern of behavioral adaptation towards human landscapes in the eastern United States. Nevertheless, we advise the closure of public areas where raven nesting sites occur and encourage researchers and managers to minimize disturbance in such areas.

In the future, we recommend that field studies be conducted which target ecological and demographic characteristics of ravens. Data from such studies may lead to a better understanding of factors responsible for its recolonization in Appalachia and to what extent the recent increase in logging and mountain-top coal mining (Kentucky Environmental Quality Commission 2001) could affect its recovery. Further, we recommend that in lieu of the recent increase in raven sightings, because ravens are easily confused with crows, and since the availability of row crop and potential depredation is minimal, that wildlife agencies suspend crow hunting in areas where ravens have been reported in order to facilitate the recolonization of this regionally threatened species. In addition, we suggest that wildlife managers and stewards, as well as county extension agents that operate in areas occupied by ravens incorporate the species into their educational programs to facilitate public awareness and generate support for its recovery.

\section{LITERATURE CITED}

Bednorz, J. 1991. The re-expansion of the raven (Corvus corax) in Poland. Pp. 29-35, In D. Glandt (Ed.). The raven (Corvus corax) in Middle Europe. Metelener Schriftenreihe Naturschutz - 2, Metelen. 117 pp.

Boarman, W.I., and K.H. Berry. 1995. Common ravens in the southwestern United States, 1968-92. Pp. 73-75, In E.T. Laroe (Ed.). Our living resources: A report to the nation on the distribution, abundance, and health of U.S. plants, animals, and ecosystems. U.S. Department of Interior, National Biological Service, Washington, DC. 481pp.

Boarman, W.I., and B. Heinrich. 1999. Common Raven. In A. Poole and F. Gill (Eds.). The Birds of North America, No. 476. The Birds of North America, Inc., Philadelphia, PA. 31pp.

Buckelew, A.R., Jr., and G.A. Hall. 1994. The West Virginia Breeding Bird Atlas. University of Pittsburgh Press, Pittsburgh, PA. 215 pp.

Cox, J.J., L. Meade, D. Yancy, and D.S. Maehr. 2001. Taxonomic status of wild Canis in Kentucky. Proceedings of the Annual Conference of Southeastern Fish and Wildlife Agencies. In press.

Croft, J.E. 1970. Ravens in eastern Kentucky. Kentucky Warbler 46:21-22.

Davis, W.H., C.K. Smith, J.E. Hudson, and G. Shields. 1980. Summer birds of Cumberland Gap National Historic Park. Kentucky Warbler 56:43-55.

Dudek, M. 2001. Of ravens and wolves - a highly evolved alliance between bird and mammal. Charadrius 37:123-126. 
Eller, R.D. Miners, Millhands, and Mountaineers: Industrialization of the Appalachian South. The University of Tennessee Press, Knoxville, TN. $272 \mathrm{pp}$.

Fowler, D.K., J.R. MacGregor, S.A. Evans, and L.E. Schaff. 1985. The common raven returns to Kentucky. American Birds 39:852-853.

Grünkorn, T. 2001. Population growth of raven (Corvus corax) in the German federal state of Schleswig-Holstein from 1991 to 2000. Charadrius 37:77-80.

Harlow, R.C. 1922. The breeding habits of the northern raven in Pennsylvania Auk 39:399-410.

Harlow, R.C., R.G. Hooper, R.D. Chamberlain, and H.S. Crawford. 1975. Some winter and nesting season food of the common raven in Virginia. Auk 92:298-306.

Harrison, H.H. 1975. A Field Guide to Birds' Nests in the United States East of the Mississippi River. Houghton-Mifflin, Co., Boston, MA. 257 pp.

Heilbrun, L.H., and CBC regional editors. 1983. The eighty-third Audubon Christmas bird count. Breaks Interstate Park, VA-KY. American Birds $37: 821$.

Hooper, R.G. 1975. Nesting habitat of common ravens in Virginia. The Wilson Bulletin 89:233-243.

Kentucky Environmental Quality Commission. 1992. State of Kentucky's environment: A report of progress and problems. Commonwealth of Kentucky, Frankfort. $332 \mathrm{pp}$.

Kilham, L. 1989. The American Crow and the Common Raven. Texas A\&M University Press. College Station, TX. 255 pp.

Knight, R.L., H.A.L. Knight, and R.J. Camp. 1993. Raven populations and landuse patterns in the Mojave Desert, California. Wildlife Society Bulletin 21:469-471.

Larkin, J.L., D.S. Maehr, M. Olsson, and P. Widen. 1999. Common ravens breeding in Knott County. Kentucky Warbler 75:50-52.

Maehr, D.S., R. Grimes, and J.L. Larkin. 1999. Initiating elk restoration: the Kentucky case study. Proceedings of the Annual Conference of Southeastern Fish and Wildlife Agencies 53:350-363.

Marzluff, J.M., B. Heinrich, and C.S. Marzluff. 1996. Raven roosts as information centres. Animal Behaviour 51:89-103.

Mech, L.D. 1970. The Wolf: the Ecology and Behavior of an Endangered Species. The Natural History Press, Garden City, NY. 384 pp.

Mengel, R.M. 1949. Evidence of the history and former distribution of the raven in Kentucky. Kentucky Warbler 25:1-6.

Mengel, R.M. 1965. Birds of Kentucky. Ornithological Monographs, No. 3. American Ornithologists Union. Allen Press, Lawrence, KS. 581 pp.

Nicholson, C.P., 1997. Atlas of the Breeding Birds of Tennessee. University of Tennessee Press, Knoxville, 426 pp.

Palmer-Ball, B., Jr. 1996. The Kentucky Breeding Bird Atlas. University of Kentucky Press, Lexington, KY. 372 pp.

Ryden, H. 1975. God's Dog. Penguin Books, New York, NY. 288 pp.

Saemann, D. 1989. The resettlement of Saxon East Germany by the raven, Corvus corax, (1758) with special consideration of the Erzgebirge. Faunistische-Abhandlungen-Dresden 16:169-182. 
Smith, C.K., and W.H. Davis. 1979. Raven and osprey in southeastern Kentucky. Kentucky Warbler 55:19-20.

Stamm, A.L. 1981. The spring migration of 1981. Kentucky Warbler 57:54-60.

Thwaites, R.G. 1904. Early Western Travels. Volume 3. Arthur H. Clark Company, Cleveland, OH. 380 pp.

White, C.M., and M. Tanner-White. 1988. Use of interstate highway overpasses and billboards for nesting by the common raven, Corvus corax. Great Basin Naturalist 48:64-67.

Wilmore, S.B. 1977. Crows, Jays, Ravens, and Their Relatives. David and Charles. London, UK. 208 pp.

Young, S.P., and E.A. Goldman. 1944. The Wolves of North America. Dover Publications, New York, NY. 636 pp.

Young, S.P., and E.A. Goldman. 1946. The Puma: Mysterious American Cat. Dover Publications, New York, NY. 358 pp. 